\title{
Barking up the right tree: comparative use of arboreal and terrestrial artificial refuges to survey reptiles in temperate eucalypt woodlands
}

Damian R. Michael ${ }^{* A, B}, \mathbf{C}$, Daniel Florance*A ${ }^{* \mathbf{A}}$, Mason Crane ${ }^{\mathbf{A}}$, Wade Blanchard ${ }^{\mathbf{A}}$ and David B. Lindenmayer ${ }^{\mathbf{A}, \mathbf{B}}$

${ }^{\mathrm{A}}$ Fenner School of Environment and Society, The Australian National University, Canberra, ACT, 2601, Australia.

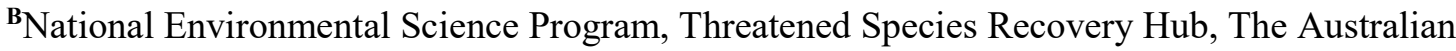
National University, Canberra, ACT, 2601, Australia.

${ }^{\mathrm{C}}$ Corresponding author. Email: damian.michael@anu.edu.au

*These authors contributed equally to this work

\begin{abstract}
Context. Artificial refuges (cover boards) are a popular method to survey and monitor herpetofauna worldwide. However, one limitation of using artificial refuges in terrestrial environments is the low detection rates of arboreal species. Furthermore, destructive search techniques can damage critical microhabitat such as exfoliating rock or flaking bark of mature trees.
\end{abstract}

Aim. We tested a non-destructive, passive method of sampling arboreal reptiles in fragmented agricultural landscapes in south-eastern Australia.

Methods. We installed 84 artificial bark refuges consisting of strips of non-toxic, closed-cell foam attached to eucalypt trees in thirteen patches of remnant vegetation. We used Bayesian statistics to compare differences in detection rates between artificial bark refuges, terrestrial artificial refuges and active searches of natural habitat over a four year period. 
Key results. Active searches combined with terrestrial artificial refuges detected the most number of reptile species, including several cryptic fossorial species. Artificial bark refuges detected on average 132 times more individuals of the arboreal southern marbled gecko Christinus marmoratus than terrestrial refuges. Gecko abundance patterns were related to tree characteristics such as tree size, bark thickness and stand basal area, as well as survey year.

Conclusions. Traditional survey methods such as terrestrial cover boards in combination with active searches of natural habitat may significantly underestimate counts for arboreal gecko species.

Implications. Artificial bark refuges provide a cost-effective, non-destructive and durable method for surveying and monitoring arboreal reptiles in woodland environments over short to medium time frames. Foil-backed, closed-cell foam has broad application for use in spatial capture-recapture studies and long-term monitoring of arboreal reptiles. This method also may be effective for procuring records of threatened arboreal geckos or as a solution for providing temporary habitat in ecological restoration projects.

Additional keywords: arboreal reptiles, artificial cover boards, environmental impact assessments, habitat restoration, survey method

\section{Introduction}

Effective wildlife management requires a detailed understanding of species distributions and habitat preferences (Adams 2016; Fryxell et al. 2014). Paramount in achieving this goal is choosing survey techniques that provide reliable estimates of abundance and diversity (Garden et al. 2007; RibeiroJúnior et al. 2008). Survey methods also must have the ability to detect and monitor changes in population trends over time (Lindenmayer et al. 2012a) and produce standardised and repeatable empirical data that can be compared across sampling events (Cunningham 2016; Engeman 2005). Survey techniques that fail to adequately detect rare and cryptic species, or particular taxonomic groups and lifeforms, may lead to incomplete inventories, inappropriate management actions and suboptimal conservation outcomes (Thompson 2013). 
The use of artificial refuges (cover boards) to detect reptiles and amphibians is now a well-established method for surveying and monitoring particular taxonomic groups, especially terrestrial snakes, lizards and amphibians (Hampton 2007; Michael et al. 2012; Sutherland et al. 2016; Willson and Gibbons 2010). A wide range of manufactured materials have been used to survey herpetofauna, including fibrocement slabs to monitor tortoises (Ballouard et al. 2013), timber boards and cedar shingles to survey salamanders in Europe, and Asia (Hesed 2012; Monti et al. 2000; Willson and Gibbons 2010), Onduline (bitumen) sheets to survey geckos in New Zealand (Thierry et al. 2009), and corrugated tin to survey snakes in the United States of America (Grant et al. 1992; Halliday and Blouin-Demers 2015; Hampton 2007; Joppa et al. 2009). In Australia, timber fence posts have been used to survey grassland reptiles (Michael et al. 2004), concrete and terracotta roofing tiles have been used to survey legless lizards (Howland et al. 2016; Thompson 2006), and recycled railway sleepers have been used to survey small, nocturnal elapid snakes (Michael et al. 2012).

The use of artificial refuges is not without limitations. Artificial refuges placed in terrestrial environments will inherently be biased towards sampling ground-dwelling fauna, and factors such as time of day and weather variables can significantly influence detection rates (Joppa et al. 2009; Thierry et al. 2009). However, several studies have detected arboreal lizards using terrestrial refuges (Michael et al. 2012). In south-eastern Australia, arboreal lizard species also use habitats other than trees, particularly rocky outcrops, fallen timber and buildings (Michael et al. 2015). Species such as the ragged snake-eyed skink Cryptoblepharus pannosus and the southern marbled gecko Christinus marmoratus have been detected on the ground beneath timber posts deployed as a survey method in woodland ecosystems (Michael et al. 2004), or beneath sheets of corrugated tin which imitate natural bark habitat (Michael et al. 2012). However, using terrestrial refuges to detect arboreal species is likely to result in low detection rates and incomplete inventories. The use of arboreal refuges is therefore likely to improve arboreal species detection rates. Although this method has primarily been applied in studies of invertebrates (Bowie et al. 2006; Hodge et al. 2007), two studies have targeted reptiles. In New Zealand, the use of arboreal covers led to the detection of more cryptic arboreal forest 
geckoes than nocturnal spotlighting, terrestrial artificial refuges or trapping (Bell 2009). In the tropical savanna woodlands of northern Australia, arboreal covers were used to compare differences in capture success between visual encounter surveys (Nordberg and Schwarzkopf 2015). However, lizard detections beneath arboreal covers have not been compared to traditional survey methods such as active searches or other forms of artificial refuges. Furthermore, the use of arboreal covers may reduce the need to remove or damage critical habitat such as exfoliating or flaking bark of mature trees. This is an important consideration when undertaking long-term ecological monitoring in areas that support threatened arboreal reptile species or threatened vegetation communities, given that once bark habitat is removed or damaged, it is not readily replaced and may take decades to accumulate. Damage to bark may also introduce a survey artefact with diminishing searchable habitat available with time since monitoring, which may be an important consideration when evaluating restoration outcomes.

To examine the effectiveness of using arboreal covers to survey and monitor temperate zone reptiles, we compared detections of arboreal reptiles between artificial bark refuges, active searches and terrestrial artificial refuges (timber railway sleepers, terracotta roofing tiles and corrugated steel) over a four year period. We addressed three questions: 1) How effective are different survey methods for detecting arboreal species? 2) Are there temporal differences in species detection rates over time? 3) Do tree characteristics (e.g. tree species, trees size class, bark thickness and stand basal area) influence arboreal lizard detection rates?

\section{Materials and methods}

Study area

We conducted this study within the Cowra-Young-Boorowa district of the South-west Slopes bioregion of New South Wales (central coordinate: $\left.34^{\circ} 06^{\prime} 30.9^{\prime \prime S} 148^{\circ} 36^{\prime} 59.6^{\prime \prime} \mathrm{E}\right)$. The predominant form of native vegetation in the bioregion is temperate eucalypt woodland (Hobbs and Yates 2000; 
Lindenmayer et al. 2016). Sites were located on pre-existing long-term monitoring sites on private land within the critically endangered Box Gum Grassy Woodland ecosystem. Sites were located in patches of remnant vegetation where livestock grazing is the dominant land use. The native overstorey species were dominated by white box (Eucalyptus albens), yellow box (E. melliodora) and Blakely's red gum (E. blakelyi) (Keith and Wales 2004).

\section{Terrestrial and arboreal artificial refuges}

In 2010, we established 268 reptile monitoring plots ( $1 \mathrm{ha}=50 \mathrm{~m} \times 200 \mathrm{~m}$ search grids) across the critically endangered White Box-Yellow Box-Blakely’s Red Gum Woodland and Derived Native Grassland ecological vegetation community in south-eastern Australia (Lindenmayer et al. 2012b). Within each permanently marked monitoring plot, we installed two arrays of terrestrial artificial refuges (Figure 1). These consisted of four timber railway sleepers (1.2 $\mathrm{m}$ in length), four terracotta roof tiles, and one double stack of $1 \mathrm{~m}^{2}$ corrugated steel sheet (Michael et al. 2012). Each array was placed $100 \mathrm{~m}$ apart along the centre of the monitoring plot. During $20^{\text {th }}-24^{\text {th }}$ May 2013 , we selected thirteen sites from a subset of pre-existing monitoring sites located within the Lachlan-Murrumbidgee catchment where arboreal lizard species (e.g. southern marbled gecko Christinus marmoratus) had been previously detected through either active searches or artificial terrestrial refuges (Kay et al. 2013). We then installed arboreal artificial bark refuges $(\mathrm{N}=84$ bark refuges) in a 1 ha area adjacent to our existing monitoring sites. The bark refuges consisted of a non-toxic, foil-backed strip of closedcell foam (NSL 40055 mm, 1000 mm wide x 50 m roll, manufactured by PJ Bowers Pty Ltd, Queensland). We cut the material into $500 \mathrm{~mm}$ wide strips and covered the entire circumference of selected tree trunks, restraining the covers with rope attached to shock cords and metal ' $\mathrm{S}$ ' clips (Figure 1). Each bark refuge was installed at a height of 1.3 metres above the ground (for logistical reasons). This attachment method allowed for quick removal from the tree to facilitate searching underneath. The foil faced outwards to provide weather resistance and thermal insulation. At each site, six trees were selected (mean distance between selected trees $=24.8 \mathrm{~m}$ ), representing the two dominant overstory species (E. blakelyi and E. melliodora) and three size classes measured at breast 
height (small: $10-30 \mathrm{~cm}$, mean $=26.18 \mathrm{~cm}$; medium: $31-60 \mathrm{~cm}$, mean $=46.56 \mathrm{~cm} ;>60 \mathrm{~cm}$, mean $=77.81 \mathrm{~cm})$. The bark refuges were positioned on trees $100 \mathrm{~m}$ from our terrestrial monitoring plots to reduce confounding effects between artificial refuge methods. Arboreal and terrestrial refuges remained in situ throughout the entire study. The total cost of all artificial bark materials (foam, rope, shock cord and clips) ranged from $\$ 5.8$ to $\$ 13.75$ AUD/tree, depending on tree circumference (approximately $\$ 6 \mathrm{AUD} / \mathrm{m}$ ). We conducted the first survey in spring, four months after the artificial bark refuges were installed, and in conjunction with active searches and inspections of terrestrial artificial refuges.

\section{Survey protocols}

We collected count data (abundance) on lizards from thirteen sites using three different survey techniques, time-constrained (20 min) active searches of natural habitat (including lifting bark of trees, logs and rocks, and conducting visual surveys of tree trunks and logs), terrestrial artificial refuges and arboreal artificial refuges. The time required to inspect the two arrays of terrestrial refuges and the bark refuges was 10 minutes for each method. We conducted one survey each year between September and November 2013, 2014, 2015 and 2016, and compared detection rates among survey methods using these years for comparison. We did not individually mark lizards in this study. All surveys were conducted by the same group of ecologists on clear days between 0900 - 1400 hours.

\section{Statistical analysis}

Differences in lizard occurrence and abundance among the three survey methods were compared using logistic and Poisson (or negative binomial when over dispersion was present) regression respectively. We chose the negative binomial model over the Poisson model using leave-one-out cross-validation information criteria (LOOIC) (Gelman et al. 2014; Vehtari et al. 2015; Watanabe 2010) which we described in more detail below. Over-dispersion was present when the negative binomial model had a lower LOOIC than the corresponding Poisson model. Data were collapsed to 
the site level for this stage of the analysis and site was used as a random effect in the regression models to account for dependence among the survey methods and for multiple visits over years. The effect of survey method was assessed by comparing models with and without different survey methods. Differences in lizard occurrence beneath bark refuges over time were compared using presence absence data at the tree level for each year. Site was fitted as a random effect and year was modelled as a categorical variable. The effect of year on occurrence rates was assessed by comparing models with and without survey year. To evaluate tree characteristics effecting abundance we fitted tree species, size class, tree diameter (measured at breast height, log transformed), stand basal area $\left(\mathrm{m}^{2} / \mathrm{ha}, \log\right.$ transformed) and bark thickness (log transformed). We did not include size class and the other size variables in the same model, since size class was associated with other tree characteristics (e.g. tree diameter, stand basal area and bark thickness). Survey year was retained in all models as this was considered important for detections. Bayesian methods were employed in all analyses using the brms (Bayesian regression models using Stan) package (Buerkner 2016) in R (R Core Team (2015). Brms provides a convenient interface to Stan (Carpenter et al. 2017) for many commonly occurring generalized linear mixed models and also provides several extensions. Cauchy priors (location $=0$, scale $=5 / 2$ ) were assigned to all regression parameters and continuous variables were standardized prior to analysis (Gelman et al. 2008). Four Hamiltonian Markov Chains were run for 2000 iterations each and convergence was assessed by visual examination of the trace plots. In the interest of model parsimony, we chose the simplest model within two LOOIC units of the best fitting model (Gelman et al. 2014; Vehtari et al. 2015; Watanabe 2010).

\section{Results}

\section{Summary statistics}

The closed-cell foam material remained viable throughout the four year deployment period suggesting this material is weather-resistant in field conditions. Damage caused by invertebrates and avifauna was evident on some foam pieces, but this did not seem to affect reptile use. Overall, we recorded 
thirteen reptile species from five families. Four reptile species were detected beneath the bark refuges, eight species were detected beneath terrestrial refuges, and eleven reptile species were detected using actives searches (Table S1, available as supplementary material to this paper). Boulenger's skink Morethia boulengeri accounted for 54\% of all reptile observations and was detected most frequently beneath corrugated steel (123 observations) followed by active searches ( 65 observations). The southern marbled gecko Christinus marmoratus accounted for 33\% of all observations and was most frequently recorded beneath artificial bark refuges (142 observations) compared to actives searches ( 7 observations) and corrugated steel (1 observation). Given the low number of detections of most lizard species beneath artificial bark refuges, we restricted our analysis to C. marmoratus.

What is the optimal survey method for detecting C. marmoratus?

The model that allowed for differences in detection of C. marmoratus among the three survey methods was highly preferred $(\Delta \mathrm{LOOIC}=66.87)$ over the model that assumed a constant detection rate among survey methods. Negative binomial models fitted our abundance of $C$. marmoratus better than the Poisson models (lower LOOIC in all cases), and the model that allowed for differences in abundance among the three survey methods was preferred to the constant abundance model $(\Delta$ LOOIC $=88.14)$. Abundance estimates from artificial bark refuges were 20.5 times $(95 \%$ credible interval 9.3, 52.4) and 132 times $(29.3,1695.5)$ higher than active search and terrestrial artificial refuges, respectively (Figure 2, Table S2, available as supplementary material to this paper). A similar difference between survey methods was observed for detection rates (Table S3, available as supplementary material to this paper).

\section{Temporal differences in detection rates}

The model that allowed for differences in detection rates of $C$. marmoratus among years was preferred to the constant detection rate model $($ LOOIC $=15.27)$. The lowest rate was observed in 2013 (8.1\% detection probability) and we found no evidence of differences in detection rates (range 
$26.2 \%-31.4 \%$ ) among subsequent survey years (2014-2016). (Table S4, available as supplementary material to this paper).

\section{Tree characteristics and bark refuge abundance}

We considered 18 models of varying degrees of complexity (see Table S5 for a complete listing available as supplementary material to this paper) to model the abundance per tree of C. marmoratus. The most parsimonious model showed the following effects: abundance per tree was positively associated with tree diameter (slope $1.06,95 \%$ credible interval $[0.77,1.36])$, bark thickness $(0.28$, $[0.09,0.48])$ and basal area $(0.23,[0.01,0.47])$ and survey year (Figure 3$)$. Abundance per tree was lower in 2013 compared to 2014-2016, with no evidence of differences among 2014-2016 (Table S6, available as supplementary material to this paper).

\section{Discussion}

In many studies of herpetofauna, a combination of survey methods is required to procure comprehensive inventories (Garden et al. 2007; Michael et al. 2012). Effective survey methods also must have the ability to detect and monitor changes in population trends over time (Lindenmayer et al. 2012a) and produce standardised and repeatable empirical data that can be compared across sampling events (Cunningham 2016; Engeman 2005). In this study, we compared detection rates of reptiles over a four year period using three different survey methods. We specifically examined the effectiveness of using a novel survey method to detect arboreal reptiles in fragmented agricultural landscapes.

We found active searches of natural habitat resulted in the greatest number of detections of reptile species. Two species (Anilios nigrescens and Lerista bougainvillii) were detected only beneath terrestrial refuges, three species (Aprasia parapulchella, Cryptoblepharus pannosus and Egernia 
cunninghami) were detected only during active searches and only one individual E. striolata was detected beneath artificial bark refuges. These findings provide evidence to suggest that using both active searches and artificial refuges such as corrugated steel to survey reptiles in temperate eucalypt woodlands can procure complimentary species (Michael et al. 2012), especially cryptic fossorial species which are often difficult to detect in highly disturbed agricultural environments. Surprisingly, we detected very few $C$. pannosus beneath bark refuges even though this species was detected more frequently during actives searches (basking on trees) during the surveys. In a similar study, Nordberg and Schwarzkopf (2015) found that Cryptoblepharus sp. was one of the most commonly detected species beneath artificial bark refuges. Given the tendency for this species to prefer heavily timbered habitats with abundant amounts of fallen timber and dead trees (Cunningham et al. 2007; Michael et al. 2014), the widespread practice of cleaning up fallen and dead timber in agricultural landscapes may have reduced its abundance in the historically heavily grazed study area that was the focus of the investigation reported here.

\section{Optimal survey method for detecting C. marmoratus}

We found significantly more individuals of $C$. marmoratus beneath artificial bark refuges than any other survey method (Figure 1). The species was 132 times more abundant beneath bark refuges than beneath terrestrial refuges, and 20 times more abundant beneath bark refuges than on sites where active searches were used. This suggests that traditional methods such as terrestrial cover boards and active searches may underestimate the abundance of this species, although this may depend on region, habitat condition and the presence of rock habitat (Lettink 2007; Michael et al. 2012). Considering we installed only six bark refuges over 1 ha and, on average, more trees were inspected (by carefully lifting exfoliating bark) during active searches, the differences in detection rates between survey methods is even more compelling. Population estimates for C. marmoratus in rocky environments have been reported to be approximately 150 animals/ha (Kearney and Predavec 2000). However, in non-rocky environments, it is difficult to locate geckos sequestered beneath the bark of trees without causing substantial damage to their habitat. If we were to comprehensively search for sheltering 
geckos by completely removing bark from all suitable trees, it is likely that active searches would produce higher detection rates, but this activity would at the same time reduce the quality of habitat for this and other arboreal species. Incorporating artificial bark refuges in future fauna surveys would not only negate the need to damage critical bark habitat but could significantly increase the probability of detecting arboreal species. This has important implications for the refinement of survey methods used to target threatened arboreal species in environmental impact assessments.

\section{Temporal differences in detection rates}

We found C. marmoratus occupied the artificial bark refuges relatively soon after they had been installed ( $8.1 \%$ detection probability at four months since installation). In the following year, detection rates beneath bark refuges had increased by a factor of four ( $31.4 \%$ detection probability), thereafter remaining stable. Over time, arboreal refuges may provide stable detection probabilities and reliable population estimates. Unlike terrestrial refuges (both natural and artificial), which are subject to considerable variability in temperature (Huey et al. 1989; Kearney 2002) and corresponding fluctuations in the occupancy patterns of cryptozoic species (Webb and Shine 1998; Thierry et al. 2009), bark habitat may provide opportunities for geckos to thermoregulate during different seasons and hence, detectability issues associated with temperature are predicted to be reduced. We suggest bark refuges may provide thermally suitable microhabitats because they are wrapped around the entire circumference of the tree, allowing individuals to select a broad range of dial and seasonal thermal conditions. Christinus mamoratus is known to regulate its body temperature through positional and postural mechanisms, as well as through retreat site selection (Kearney and Predavec 2000). Artificial bark refuges may provide a range of thermally suitable microhabitats that may promote long-term occupation and site fidelity. Further research is required to examine the relationship between gecko occupancy patterns and the thermal conditions of artificial refuges compared to natural retreat sites. 
Previous studies in the temperate eucalypt woodlands of south-eastern Australia have reported $C$. marmoratus to be an arboreal generalist (Michael et al. 2015), associated with old growth vegetation (Cunningham et al. 2007), large trees and high amounts of native vegetation in the landscape (Michael et al. 2017). In this study, we found the majority of C. marmoratus observations beneath bark refuges were from trees with an average diameter of $78 \mathrm{~cm}$. We also found between $20-40 \%$ of C. marmoratus observations were on trees with an average diameter of $47 \mathrm{~cm}$. The model which best explained C. marmoratus abundance patterns included tree diameter, bark thickness and stand basal area as important variables (Figure 2). These findings suggest that large diameter trees with thick bark located in timbered areas, regardless of tree species may be the best trees to target for artificial bark installation for future herpetofauna inventory and monitoring projects.

Our findings also suggest that artificial bark refuges may have broad application in ecological restoration programs, especially in relation to increasing arboreal habitat in secondary vegetation communities (regrowth woodland) where stem density is high and tree size is small (Ikin et al. 2015). Bark refuges placed in areas that lack large trees with suitable bark habitat could facilitate greater dispersal and gene flow between lizard populations that occur in fragmented agricultural landscapes. Habitat loss and fragmentation can disrupt fine-scale movements and dispersal capabilities of some arboreal species (Hoehn et al. 2007), prompting some researchers to suggest creating 'stepping stone' habitats as a method for improving connectivity for arboreal geckos (Kay et al. 2016).

\section{Implications for research and management}

Artificial bark refuges led to the detection of substantially more individuals of the arboreal $C$.

marmoratus than terrestrial artificial refuges or active searches suggesting that traditional survey methods may significantly underestimate the abundance of this species. The foil-backed, closed-cell foam product used in this study was weather resistant over the four years of field deployment, suggesting that it is a suitable material for use in short to medium-term studies. Artificial bark refuges 
also provide a cost-effective and non-invasive, practical method for surveying arboreal nocturnal reptiles and will thereby reduce the need to damage critical bark habitat when conducting fauna surveys or environmental impact assessments. The need to preserve bark habitat is extremely important as, for some tree species, this micro-resource can take decades to accumulate and may not be readily renewed when destroyed or damaged. Longer-term assessment of the durability of this product in the field will continue. For long-term studies, alternative materials may be required and it is recommended that alternative products are tested in the field.

Bark refuges have enormous potential for use in spatial capture-recapture studies (Sutherland et al. 2016) or for obtaining empirical spatial data on rare and cryptic arboreal species (Bell 2009). For inventory and monitoring projects, a combination of census techniques will provide the greatest diversity and detection of herpetofauna and it is recommended that artificial bark installation be considered to complement other survey methods. An observed delay in herpetofauna colonisation following artificial bark installation should be considered when planning deployment of artificial bark and monitoring schedules. The use of artificial bark refuges also has application as a temporary solution to creating arboreal habitat in ecological restoration programs that aim to improve habitat connectivity in fragmented agricultural landscapes. We recommend that further research focus on the use of bark refuges as a habitat restoration tool and as a method for procuring records for threatened arboreal reptiles in different woodland and forest ecosystems.

\section{Acknowledgments}

We thank the following organisations for providing financial or logistic support, the National Environmental Science Program Threatened Species Recovery Hub, Australian Research Council, Murray Local Land Services, Riverina Local land Services, Central Tablelands Local land Services, Holbrook Landcare Network, NSW Environment Trust, Ian Potter Foundation and the Vincent Fairfax Family Foundation. We thank key members of our field team whom assisted with data 
collection, Christopher MacGregor, David Blair, Lachlan McBurney, Geoff Kay, Thea O’Loughlin, David Smith, Clare Crane and Sachiko Okada. The authors declare no conflicts of interest. This work was conducted under the NSW National Parks and Wildlife scientific license (SL100969) and was approved by the Australian National University Animal Care and Ethics Committee (A2016-39).

\section{References}

Adams, C. E. (2016) 'Urban Wildlife Management.' (CRC press, Taylor \& Francis Group: Boca Raton.)

Ballouard, J.-M., Caron, S., Lafon, T., Servant, L., Devaux, B., and Bonnet, X. (2013). Fibrocement slabs as useful tools to monitor juvenile reptiles: a study in a tortoise species. Amphibia-Reptilia 34, $1-10$.

Bell, T. P. (2009). A novel technique for monitoring highly cryptic lizard species in forests. Herpetological Conservation and Biology 4, 415-425.

Bowie, M. H., Hodge, S., Banks, J. C., and Vink, C. J. (2006). An appraisal of simple tree-mounted shelters for non-lethal monitoring of weta (Orthoptera: Anostostomatidae and Rhaphidophoridae) in New Zealand nature reserves. Journal of Insect Conservation 10, 261-268.

Buerkner, P.-C. (2016). brms: An R package for Bayesian multilevel models using Stan. Available at: https://cran.r-project.org/web/packages/brms/vignettes/brms.pdf.

Bob Carpenter, Andrew Gelman, Matthew D. Hoffman, Daniel Lee, Ben Goodrich, Michael Betancourt, Marcus Brubaker, Jiqiang Guo, Peter Li, and Allen Riddell. 2017. Stan: A probabilistic programming language. Journal of Statistical Software 76(1). DOI 10.18637/jss.v076.i01

Cunningham, R. B. (2016). Design and analysis of quasi-experiments in landscape ecology: responses of fauna to landscape vegetation transformation in South-Eastern NSW. PhD Thesis (The Australian National University, Canberra, ACT.)

Cunningham, R. B., Lindenmayer, D. B., Crane, M., Michael, D., and MacGregor, C. (2007). Reptile and arboreal marsupial response to replanted vegetation in agricultural landscapes. Ecological Applications 17, 609-619.

Engeman, R. M. (2005). Indexing principles and a widely applicable paradigm for indexing animal populations. Wildlife Research 32, 203-210.

Fryxell, J. M., Sinclair, A. R., and Caughley, G. (2014) 'Wildlife Ecology, Conservation and Management.' (John Wiley \& Sons: UK)

Garden, J. G., McAlpine, C. A., Possingham, H. P., and Jones, D. N. (2007). Using multiple survey methods to detect terrestrial reptiles and mammals: what are the most successful and cost-efficient combinations? Wildlife Research 34, 218-227.

Gelman, A., Hwang, J., and Vehtari, A. (2014). Understanding predictive information criteria for Bayesian models. Statistics and Computing 24, 997-1016.

Gelman, A., Jakulin, A., Pittau, M. G., and Su, Y.-S. (2008). A weakly informative default prior distribution for logistic and other regression models. The Annals of Applied Statistics 2, 1360-1383. 
Grant, B. W., Tucker, A. D., Lovich, J. E., Mills, A. M., Dixon, P. M., and Gibbons, J. W. (1992). The use of coverboards in estimating patterns of reptile and amphibian biodiversity. In 'Wildlife 2001: Populations'. (Ed. D. R McCullough \& Barrett, R. H.) pp. 379-403. (Springer: Netherlands)

Halliday, W. D. and Blouin-Demers, G. (2015). Efficacy of coverboards for sampling small northern snakes. Herpetology Notes 8, 309-314.

Hampton, P. (2007). A comparison of the success of artificial cover types for capturing amphibians and reptiles. Amphibia-Reptilia 28, 433-437.

Hesed, K. M. (2012). Uncovering salamander ecology: a review of coverboard design. Journal of Herpetology 46, 442-450.

Hobbs, R. J. and Yates, C. J. (2000) 'Temperate Eucalypt Woodlands in Australia: Biology, Conservation, Management and Restoration.' (Surrey Beatty \& Sons Pty: Sydney)

Hodge, S., Vink, C. J., Banks, J. C., and Bowie, M. H. (2007). The use of tree-mounted artificial shelters to investigate arboreal spider communities in New Zealand nature reserves. Journal of Arachnology 35, 129-136.

Hoehn, M., Sarre, S., and Henle, K. (2007). The tales of two geckos: does dispersal prevent extinction in recently fragmented populations? Molecular Ecology 16, 3299-3312.

Howland, B. W., Stojanovic, D., Gordon, I. J., Fletcher, D., Snape, M., Stirnemann, I. A., and Lindenmayer, D. B. (2016). Habitat preference of the striped legless lizard: Implications of grazing by native herbivores and livestock for conservation of grassland biota. Austral Ecology 41, 461-470.

Huey, R. B., Peterson, C. R., Arnold, S. J., and Porter, W. P. (1989). Hot rocks and not-so-hot rocks: retreat-site selection by garter snakes and its thermal consequences. Ecology 70, 931-944.

Ikin, K., Mortelliti, A., Stein, J., Michael, D., Crane, M., Okada, S., Wood, J., and Lindenmayer, D. (2015). Woodland habitat structures are affected by both agricultural land management and abiotic conditions. Landscape Ecology 30, 1387-1403.

Joppa, L. N., Williams, C. K., Temple, S. A., and Casper, G. S. (2009). Environmental factors affecting sampling success of artificial cover objects. Herpetological Conservation and Biology $\mathbf{5}$, $143-148$.

Kay, G. M., Driscoll, D. A., Lindenmayer, D. B., Pulsford, S. A., and Mortelliti, A. (2016). Pasture height and crop direction influence reptile movement in an agricultural matrix. Agriculture, Ecosystems \& Environment 235, 164-171.

Kay, G. M., Michael, D. R., Crane, M., Okada, S., MacGregor, C., Florance, D., Trengove, D., McBurney, L., Blair, D. and Lindenmayer, D. B. (2013) A list of reptiles and amphibians from Box Gum Grassy Woodlands in south-eastern Australia. Check List 9, 476-481.

Kearney, M. (2002). Hot rocks and much-too-hot rocks: seasonal patterns of retreat-site selection by a nocturnal ectotherm. Journal of Thermal Biology 27, 205-218.

Kearney, M. and Predavec, M. (2000). Do nocturnal ectotherms thermoregulate? A study of the temperate gecko Christinus marmoratus. Ecology 81, 2984-2996.

Keith, D. A. and Wales, N. S. (2004) 'Ocean Shores to Desert Dunes: The Native Vegetation of New South Wales and the ACT.' (Department of Environment and Conservation: NSW.)

Lettink, M. (2007). Comparison of two techniques for capturing geckos in rocky habitat. Herpetological Review 38, 415.

Lindenmayer, D. B., Gibbons, P., Bourke, M., Burgman, M., Dickman, C. R., Ferrier, S., Fitzsimons, J., Freudenberger, D., Garnett, S. T., and Groves, C. (2012a). Improving biodiversity monitoring. Austral Ecology 37, 285-294. 
Lindenmayer, D. B., Michael, D. R. Crane, M., Barton, P., Ikin, K., Okada, S. (2016) 'Wildlife Conservation in Farm Landscapes'. (CSIRO Publishing: Collingwood, Melbourne.)

Lindenmayer, D. B., Zammit, C., Attwood, S. J., Burns, E., Shepherd, C. L., Kay, G., and Wood, J. (2012b). A novel and cost-effective monitoring approach for outcomes in an Australian biodiversity conservation incentive program. PloS one 7, e50872.

Michael, D. R., Cunningham, R. B., Donnelly, C. F., and Lindenmayer, D. B. (2012). Comparative use of active searches and artificial refuges to survey reptiles in temperate eucalypt woodlands. Wildlife Research 39, 149-162.

Michael, D. R., Ikin, K., Crane, M., Okada, S., and Lindenmayer, D. B. (2017). Scale-dependent occupancy patterns in reptiles across topographically different landscapes. Ecography 40, 415-424

Michael, D. R., Kay, G. M., Crane, M., Florance, D., MacGregor, C., Okada, S., McBurney, L., Blair, D., and Lindenmayer, D. B. (2015). Ecological niche breadth and microhabitat guild structure in temperate Australian reptiles: Implications for natural resource management in endangered grassy woodland ecosystems. Austral Ecology 40, 651-660.

Michael, D. R., Lunt, I. D., and Robinson, W. A. (2004). Enhancing fauna habitat in grazed native grasslands and woodlands: use of artificially placed log refuges by fauna. Wildlife Research 31, 6571.

Michael, D. R., Wood, J. T., Crane, M., Montague-Drake, R., and Lindenmayer, D. B. (2014). How effective are agri-environment schemes for protecting and improving herpetofaunal diversity in Australian endangered woodland ecosystems? Journal of Applied Ecology, 51, 494-504.

Monti, L., Hunter, M., and Witham, J. (2000). An evaluation of the artificial cover object (ACO) method for monitoring populations of the redback salamander Plethodon cinereus. Journal of Herpetology 34, 624-629.

Nordberg, E. J. and Schwarzkopf, L. (2015). Arboreal cover boards: using artificial bark to sample cryptic arboreal lizards. Herpetologica 71, 268-273.

R Core Team (2015) R: A language and environment for statistical computing. R Foundation for Statistical Computing, Vienna, Austria. URL https://www.R-project.org/.

Ribeiro-Júnior, M. A., Gardner, T. A., and Ávila-Pires, T. C. (2008). Evaluating the effectiveness of herpetofaunal sampling techniques across a gradient of habitat change in a tropical forest landscape. Journal of Herpetology 42, 733-749.

Sutherland, C., Muñoz, D. J., Miller, D. A., and Grant, E. H. C. (2016). Spatial capture-recapture: a promising method for analyzing data collected using artificial cover objects. Herpetologica 72, 6-12.

Thierry, A., Lettink, M., Besson, A. A., and Cree, A. (2009). Thermal properties of artificial refuges and their implications for retreat-site selection in lizards. Applied Herpetology 6, 307-326.

Thompson, M. J. (2006) The use of artificial refuges to census populations of the 'threatened'striped legless lizard, Delma impar in Western Victoria. (Department of Zoology: La Trobe University.)

Thompson, W. (2013) 'Sampling rare or elusive species: concepts, designs, and techniques for estimating population parameters.' (Island Press: Washington, DC.)

Vehtari, A., Gelman, A., and Gabry, J. (2015). Efficient implementation of leave-one-out crossvalidation and WAIC for evaluating fitted Bayesian models. arXiv preprint arXiv:1507.04544. https://github.com/jgabry/loo.

Watanabe, S. (2010). Asymptotic equivalence of Bayes cross validation and widely applicable information criterion in singular learning theory. Journal of Machine Learning Research 11, 35713594. 
Webb, and Shine, R. (1998) Using thermal ecology to predict retreat-site selection by an endangered snake species. Biological Conservation 86, 233-242.

Willson, J. D. and Gibbons, J. W. (2010). Drift fences, coverboards, and other traps. In 'Amphibian Ecology and Conservation: A Handbook of Techniques'. (Ed. C. K. Dodd.) pp. 229-245. (Oxford University Press: New York.) 

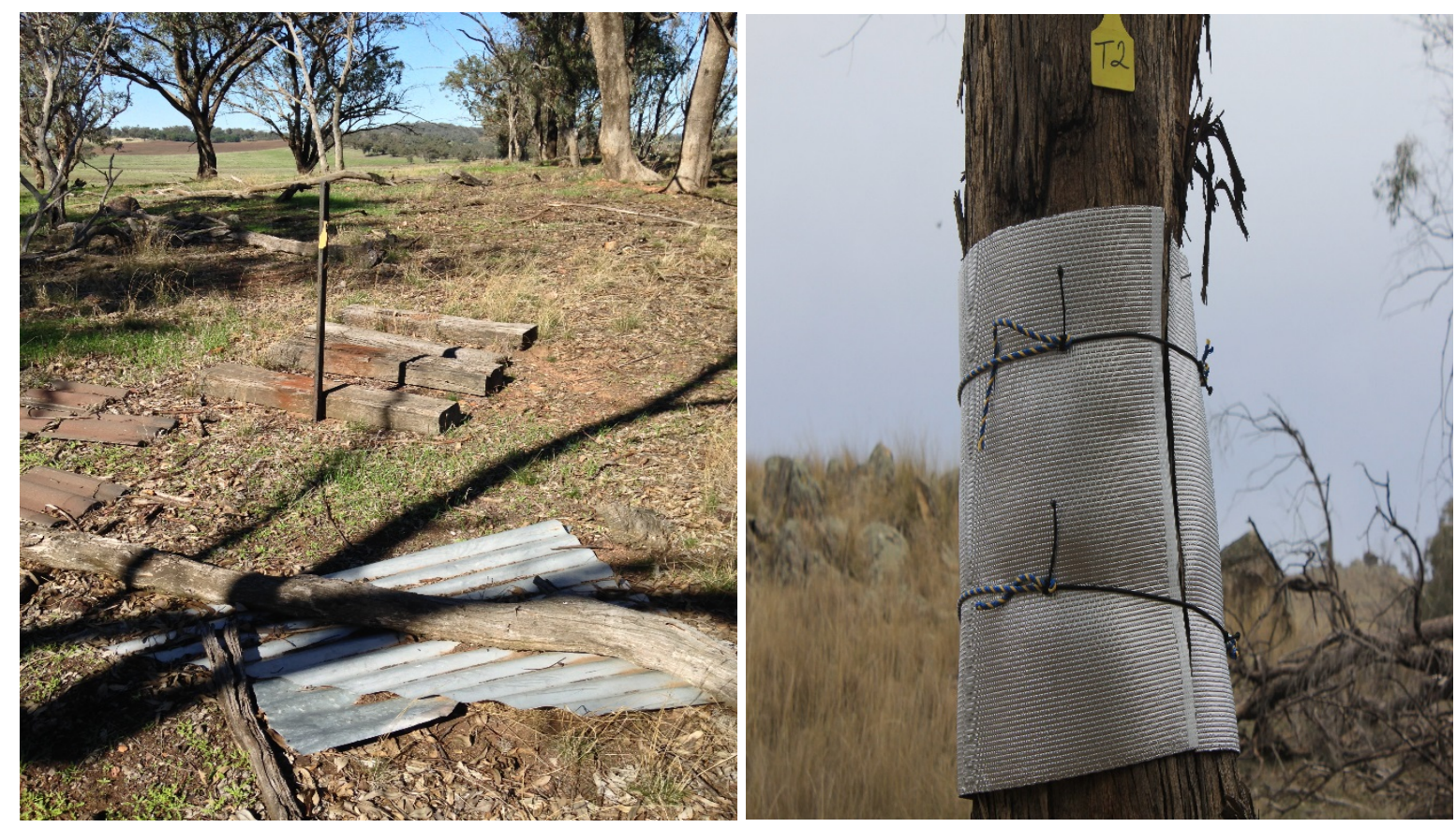

Figure 1. Terrestrial artificial refuges (left), double stack of corrugated steel, roofing tiles and timber railway sleepers. Foil-backed, closed-cell foam (right) used as an arboreal artificial bark refuge. 


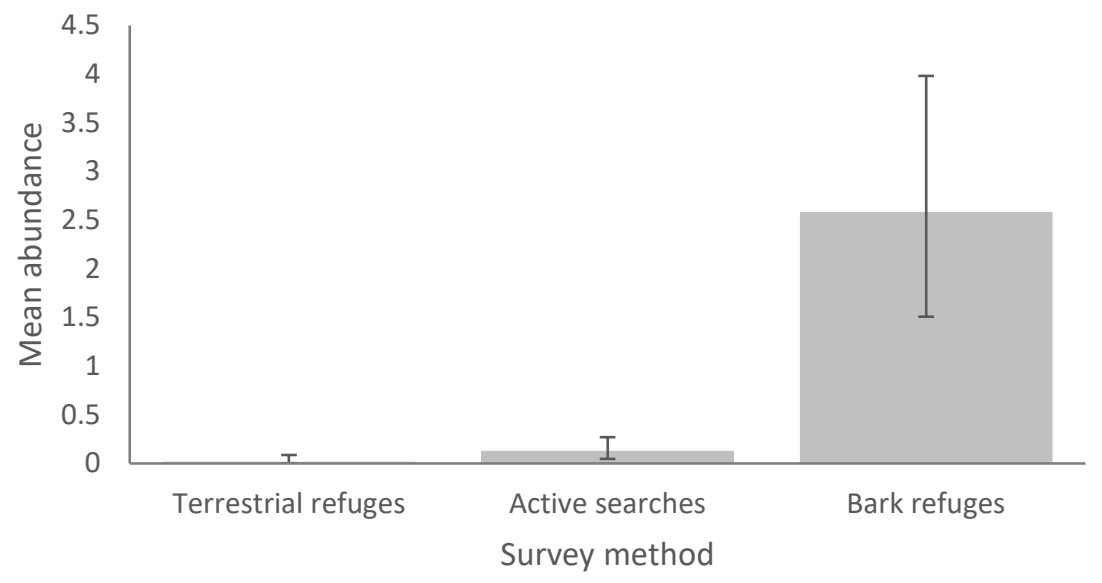

Figure 2. Mean abundance (95\% credible interval) of the southern marbled gecko Christinus marmoratus using three different survey methods between 2013 and 2016. 

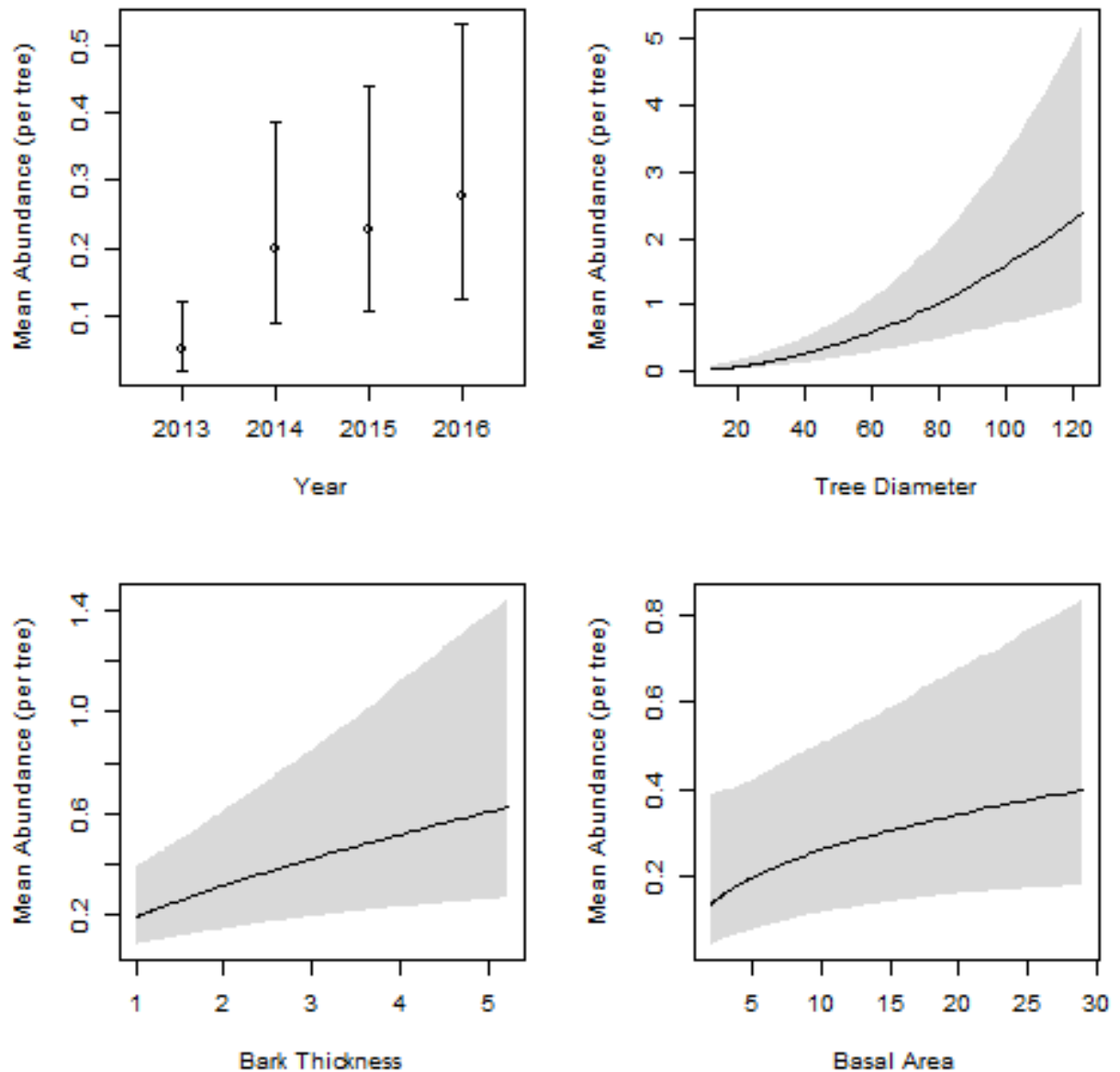

Figure 3. Relationships between the abundance of the southern marbled gecko Christinus marmoratus and survey year, tree diameter $(\mathrm{cm})$, bark thickness $(\mathrm{cm})$ and stand basal area $\left(\mathrm{m}^{2} / \mathrm{ha}\right)$ with $95 \%$ credible intervals. 


\section{Supplementary material}

Barking up the right tree: comparative use of arboreal and terrestrial artificial refuges to survey reptiles in temperate eucalypt woodlands

Damian R. Michael ${ }^{\mathbf{A}, \mathbf{B}, \mathbf{C}}$, Daniel Florance ${ }^{\mathbf{A}}$, Mason Crane ${ }^{\mathbf{A}}$, Wade Blanchard ${ }^{\mathbf{A}}$ and David B.

Lindenmayer ${ }^{\mathbf{A}, \mathbf{B}}$

${ }^{\mathrm{A}}$ Fenner School of Environment and Society, The Australian National University, Canberra, ACT, 2601, Australia.

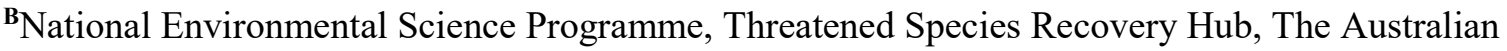
National University, Canberra, ACT, 2601, Australia.

CCorresponding author. Email: damian.michael@anu.edu.au 
Table S1. List of reptile species recorded and the total number of detections between 2013 and 2016 (four surveys) using three different survey methods: arboreal artificial refuges, actives searches and terrestrial artificial refuges (corrugated steel, timber railway sleepers and terracotta roofing tiles). Note: individual animals were not marked, so numbers for some species may represent multiple detections over survey years.

\begin{tabular}{|c|c|c|c|c|c|c|c|}
\hline Common Name & Species & Ẽ & 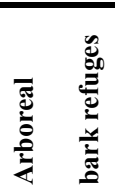 & 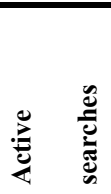 & 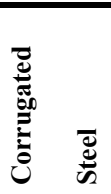 & 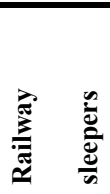 & 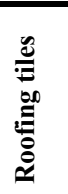 \\
\hline \multicolumn{8}{|l|}{ Gekkonidae } \\
\hline Southern Marbled Gecko & Christinus marmoratus & Arboreal & 142 & 7 & 1 & 0 & 0 \\
\hline Thick-tailed Gecko & Underwoodisaurus milii & Terrestrial & 0 & 1 & 0 & 0 & 0 \\
\hline \multicolumn{8}{|l|}{ Pygopodidae } \\
\hline Pink-tailed Worm-lizard & Aprasia parapulchella & Fossorial & 0 & 1 & 0 & 0 & 0 \\
\hline Olive Legless Lizard & Delma inornata & Terrestrial & 0 & 1 & 0 & 0 & 0 \\
\hline \multicolumn{8}{|l|}{ Scincidae } \\
\hline Southern Rainbow Skink & Carlia tetradactyla & Terrestrial & 0 & 5 & 3 & 2 & 1 \\
\hline Ragged Snake-eyed Skink & Cryptoblepharus pannosus & Arboreal & 4 & 11 & 0 & 0 & 0 \\
\hline Eastern Striped Skink & Ctenotus spaldingi & Terrestrial & 0 & 6 & 8 & 4 & 5 \\
\hline Cunningham's Skink & Egernia cunninghami & Terrestrial & 0 & 1 & 1 & 1 & 1 \\
\hline Tree Skink & E. striolata & Arboreal & 1 & 0 & 0 & 0 & 0 \\
\hline Three-toed Earless Skink & Hemiergis talbingoensis & Fossorial & 0 & 0 & 1 & 0 & 0 \\
\hline South-eastern Slider & Lerista bougainvillii & Fossorial & 0 & 0 & 1 & 0 & 0 \\
\hline Dwarf Skink & Menetia greyii & Terrestrial & 0 & 2 & 0 & 0 & 0 \\
\hline Boulenger's Skink & Morethia boulengeri & Terrestrial & 1 & 65 & 123 & 15 & 43 \\
\hline \multicolumn{8}{|l|}{ Typhlopidae } \\
\hline Blackish Blind Snake & Anilios nigrescens & Fossorial & 0 & 0 & 1 & 0 & 0 \\
\hline \multicolumn{8}{|l|}{ Elapidae } \\
\hline Dwyer's Snake & Parasuta dwyeri & Terrestrial & 0 & 1 & 0 & 0 & 0 \\
\hline Total number of species & & & 4 & 11 & 8 & 4 & 4 \\
\hline
\end{tabular}


Table S2. Abundance per site estimates of Christinus marmoratus by survey method and relative differences of survey methods. The upper part of the table gives the posterior estimates of the probability of detection and the associated $95 \%$ credible limits. The lower portion of the table, gives relative ratios and their associated $95 \%$ credible limit for comparison of rates between any two years. Note, that if the $95 \%$ credible limit does not include 1 , we conclude there is evidence of a difference between the two detection rates being compared.

\begin{tabular}{|c|c|c|c|}
\hline Group & $\begin{array}{r}\text { Estimated } \\
\text { abundance } \\
\text { per site }\end{array}$ & Lower $95 \%$ credible interval & Upper $95 \%$ credible interval \\
\hline Active searches & 0.126 & 0.047 & 0.277 \\
\hline Terrestrial refuges & 0.019 & 0.002 & 0.087 \\
\hline Bark refuges & 2.585 & 1.508 & 3.982 \\
\hline Relative Differences & & & \\
\hline $\begin{array}{r}\text { Terrestrial refuges vs } \\
\text { active searches }\end{array}$ & 0.156 & 0.011 & 0.837 \\
\hline Bark refuges vs active searches & 20.594 & 9.267 & 52.375 \\
\hline Bark vs terrestrial refuges & 132.005 & 29.323 & 1695.457 \\
\hline
\end{tabular}


Table S3. Detection rates of Christinus marmoratus by survey method and odds ratios comparing survey methods. The upper part of the table gives the posterior estimates of the probability of detection and the associated $95 \%$ credible limits. The lower portion of the table, gives the odds ratios and their associated $95 \%$ credible limit for comparison of odds ratios between any two years. Note, that if the $95 \%$ credible limit does not include 1 , we conclude there is evidence of a difference between the two detection rates being compared.

\begin{tabular}{|r|r|r|r|}
\hline Group & $\begin{array}{r}\text { Probability of detection } \\
\text { per site }\end{array}$ & Lower 95\% CI & Upper 95\% CI \\
\hline Active searches & $12.9 \%$ & $4.5 \%$ & $26.7 \%$ \\
\hline Terrestrial refuges & $1.8 \%$ & $0.1 \%$ & $8.0 \%$ \\
\hline Bark refuges & $75.5 \%$ & $58.1 \%$ & $88.9 \%$ \\
\hline Comparisons (Odds Ratio Scale) & & & 0.13 \\
\hline Terrestrial refuges vs & & 0.01 & \\
\hline active searches & & & 78.67 \\
\hline Bark refuge vs active searches & 21.86 & 7.11 & 2988.32 \\
\hline Bark vs terrestrial refuge & 174.00 & 30.74 & \\
\hline
\end{tabular}


Table S4. Detection rates per tree of Christinus marmoratus by year and odds ratios comparing yearly detection rates. The upper part of the table gives the posterior estimates of the probability of detection and the associated $95 \%$ credible limits. The lower portion of the table, gives the odds ratios and their associated $95 \%$ credible limit for comparison of odds ratios between any two years. Note, that if the $95 \%$ credible limit does not include 1 , we conclude there is evidence of a difference between the two detection rates being compared.

\begin{tabular}{|l|l|l|l|}
\hline Survey Year & $\begin{array}{l}\text { Probability of } \\
\text { detection per tree }\end{array}$ & Lower 95\% CI & Upper 95\% CI \\
\hline 2013 & $8.1 \%$ & $2.9 \%$ & $17.4 \%$ \\
\hline 2014 & $31.4 \%$ & $17.1 \%$ & $48.8 \%$ \\
\hline 2015 & $28.5 \%$ & $14.7 \%$ & $45.6 \%$ \\
\hline 2016 & $26.2 \%$ & $12.8 \%$ & $43.0 \%$ \\
\hline Comparisons (Odds Ratio Scale) & & & 13.24 \\
\hline 2014 v 2013 & 5.16 & 2.32 & 11.67 \\
\hline 2015 v 2013 & 4.49 & 1.98 & 10.53 \\
\hline 2016 v 2013 & 4.03 & 1.67 & 1.71 \\
\hline 2015 v 2014 & 0.86 & 0.43 & 1.58 \\
\hline 2016 v 2014 & 0.77 & 0.36 & 1.92 \\
\hline 2016 v 2015 & 0.90 & 0.41 & \\
\hline
\end{tabular}


Table S5. Summary of models used to explain Christinus marmoratus abundance beneath bark refuges and tree characteristics. We used the following short hand to specify the models in the table: $\mathrm{SY}=$ survey year, $\mathrm{TS}=$ tree species, $\mathrm{SC}=$ size class, $\mathrm{BA}=\log$ basal area, $\mathrm{BT}=\log$ bark thickness, $\mathrm{D}$ $=\log$ tree diameter and LOOIC $=$ leave one out information criteria.

\begin{tabular}{|c|c|c|c|}
\hline Model No & Model & No Terms & LOOIC \\
\hline 1 & SY & 1 & 541.40 \\
\hline 2 & $\mathrm{SY}+\mathrm{TS}$ & 2 & 541.93 \\
\hline 3 & $\mathrm{SY}+\mathrm{SC}$ & 2 & 459.44 \\
\hline 4 & $\mathrm{SY}+\mathrm{TS}+\mathrm{SC}$ & 3 & 459.82 \\
\hline 5 & $\mathrm{SY}+\mathrm{TS}+\mathrm{BA}$ & 3 & 536.35 \\
\hline 6 & $\mathrm{SY}+\mathrm{TS}+\mathrm{BT}$ & 3 & 500.09 \\
\hline 7 & $\mathrm{SY}+\mathrm{TS}+\mathrm{BA}+\mathrm{BT}$ & 4 & 499.83 \\
\hline 8 & $\mathrm{SY}+\mathrm{TS}+\mathrm{D}$ & 3 & 441.14 \\
\hline 9 & $\mathrm{SY}+\mathrm{TS}+\mathrm{D}+\mathrm{BA}$ & 4 & 438.11 \\
\hline 10 & $\mathrm{SY}+\mathrm{TS}+\mathrm{D}+\mathrm{BT}$ & 4 & 437.01 \\
\hline 11 & $\mathrm{SY}+\mathrm{BA}$ & 2 & 535.08 \\
\hline 12 & $\mathrm{SY}+\mathrm{BT}$ & 2 & 504.18 \\
\hline 13 & $\mathrm{SY}+\mathrm{BA}+\mathrm{BT}$ & 3 & 502.26 \\
\hline 14 & $\mathrm{SY}+\mathrm{D}$ & 2 & 441.05 \\
\hline 15 & $\mathrm{SY}+\mathrm{D}+\mathrm{BA}$ & 3 & 438.14 \\
\hline 16 & $S Y+D+B T$ & 3 & 435.33 \\
\hline 17 & $\mathrm{SY}+\mathrm{D}+\mathrm{BA}+\mathrm{BT}$ & 4 & 433.14 \\
\hline 18 & $\mathrm{SY}+\mathrm{TS}+\mathrm{D}+\mathrm{BT}+\mathrm{BA}$ & 5 & 433.77 \\
\hline
\end{tabular}


Table S6. Best fitting model for the abundance per tree estimates of Christinus marmoratus for the bark refuge. Note, that the continuous variables have been standardized (on the log scale). We also present the estimated abundance per tree by year assuming tree with the continuous covariates set at their mean value.

\begin{tabular}{|l|l|l|l|}
\hline Parameter & Estimate & Lower 95\% CI & Upper 95\% CI \\
\hline Intercept (2013) & -2.95 & -3.88 & -2.11 \\
\hline 2014 & 1.32 & 0.70 & 2.04 \\
\hline 2015 & 1.46 & 0.82 & 2.16 \\
\hline 2016 & 1.65 & 1.03 & 2.34 \\
\hline Log tree diameter & 1.06 & 0.77 & 1.36 \\
\hline Log bark thickness & 0.28 & 0.09 & 0.48 \\
\hline Log stand basal area & 0.23 & 0.01 & 0.47 \\
\hline Random effect SE & 1.08 & 0.62 & 1.84 \\
\hline Year estimates & Abundance per tree & Lower 95\% CI & Upper 95\% CI \\
\hline 2013 & 0.05 & 0.02 & 0.12 \\
\hline 2014 & 0.20 & 0.09 & 0.39 \\
\hline 2015 & 0.23 & 0.11 & 0.44 \\
\hline 2016 & 0.28 & 0.13 & 0.53 \\
\hline Relative differences & & 2.80 & 1.74 \\
\hline 2014 v 2013 & 3.72 & 0.74 & 2.12 \\
\hline 2015 v 2013 & 4.25 & 0.90 & 1.86 \\
\hline 2016 v 2013 & 5.14 & 0.80 & \\
\hline 2015 v 2014 & 1.21 & & \\
\hline 2016 v 2014 & & & \\
\hline 2016 v 2015 & & & \\
\hline
\end{tabular}


